\title{
The Contract of the Social Security Agency for Employment (BPJS Ketenagakerjaan) in The Perspective of Sharîa Economic Law
}

\author{
Bahjatul Imaniyah \\ Universitas Nurul Jadid, Jl. P.P. Nurul Jadid, Karanganyar, Probolinggo \\ Email: bahjatulimaniyah16@gmail.com
}

Article history: Received: 13 Maret 2019, Accepted: 27 Juni 2019, Published: 11 Juli 2019

\begin{abstract}
:
In providing social security, the government requires all Indonesian workers to become members of the BPJS Employment. However, because the majority of the population is Muslim who live based on the laws of the Quran and Sunnah, it is necessary to review whether the BPJS Employment has fulfilled the sharia economic law or not. By applying the method of normative legal research and interview techniques to parties concerned, this study concludes that the contract of the BPJS Employment program does not deviate from the sharia economic law (Islamic economic law) because, in the compensation on accident during the work program (JKK) it can be categorized as tabarru' contract which only applies to virtue. The Death Insurance program (JKM) is an implementation of alta'mîn al-ta'âwunî̀, which is ta'âwun in a tabarru' contract. As for the Old Age security program (JHT), it's concept is similar to the contract of mudlârabah musytarakah. The same goes for the Pension Insurance (JP) program as a transition from the contract for wârits.
\end{abstract}

Keywords:

Employment BPJS; Contract; Sharia Economic Law

Abstrak:
Untuk semua instansi maupun individu yang bekerja di negara
Indonesia diwajibkan untuk menjadi anggota Badan
Author correspondence email: bahjatulimaniyah16@gmail.com
Available online at: http://ejournal.iainmadura.ac.id/index.php/alihkam/
Copyright (c) 2019 by al-ihkam. All Right Reserved


Penyelenggara Jaminan Sosial (BPJS) Ketenagakerjaan untuk menjamin hidupnya saat bekerja. Indonesia yang mayoritas penduduknya muslim mempertimbangkan kembali akad yang ada di BPJS Ketenagakerjaan tersebut. Dengan menggunakan metode kualitatif, tulisan ini ingin mengetahui akad yang terjadi dalam BPJS Ketenagakerjaan guna menjawab beberapa pertanyaan masyarakat Indonesia terkhususnya yang beragama Islam (Muslim). Berdasarkan hasil pembahasan, akad program BPJS Ketenagakerjaan tidak menyimpang dari hukum ekonomi syarî'ah (hukum ekonomi Islam) karena, pada program Jaminan Kecelakaan Kerja (JKK) termasuk akad tabarru' yang hanya dilaksanakan pada hal kebajikan saja. Pada program Jaminan Kematian (JKM) merupakan implementasi dari al-ta'mîn alta'âwunî yaitu ta'âwun dalam akad tabarru'. Untuk program Jaminan Hari Tua (JHT), program ini memiliki konsep seperti akad mudlârabah musytarakah. Begitu pula dengan program Jaminan Pensiun (JP) sebagai peralihan dari akad wârits.

Kata Kunci:

BPJS Ketenagakerjaan; Akad; Ekonomi Syarîah; Kesejahteraan

\section{Introduction}

Islam is a religion which is based on the laws of the Qur'an and Sunnah, so that in worshiping the God, and in social and economic matters a Muslim will follow the established law. In everyday life, there are halal and haram terms which are included in the scope of the economy which are also closely related to law and sharia. To this point, economic activities which are based on Islamic law aimed at obtaining happiness are needed. There are some characteristics of sharia economics, namely: a) Divine values that make people grateful for the pleasure they enjoy b) Basic value of ownership (al-milkiyah) in the sense that the pleasures experienced by humans are entrusted from God. This is because the ownership by human is relative and not absolute which tends to squander wealth. c) Balance value (almuwâzanah) which is a value that is contrary to capitalist economic value. With the value, humans will consider individual and universal interests, worldly and the hereafter interests, rights and obligations, as well as the circulation of wealth. d) Basic values of brotherhood and togetherness (al-ukhuwwâh wa al-isytirâkiyyah wa al-jamâ'ah). This 
value makes the wealth needed by the community globally taken over by the government to prevent community disputes and disputes from different races, ethnicities and religions. e) Basic value of freedom ( $a l$ istiqlâliyyah). This value respects human freedom in utilizing assets but still restricts things that are prohibited by Islamic law. f) Basic values of justice (al- 'adâlah), fairness in this case means caring for the needy, the poor and $d h u^{\prime} a f \hat{a}$, and oppressed people.

Therefore, in Islam there are zakat, infaq and shâdaqah which might help the economy or the needs of the community. In this case, the government develops and maximizes the National Board of Zakat (BAZNAS) for the poor and / or the needy. ${ }^{1}$ In the social sphere, what is related to the Islamic economy has been implemented since the time of the Prophet Muhammad. ${ }^{2}$ The sharia also discusses and considers human life in its capacity as a "worker" and of course contains principles, rules and conceptions of "work" and teachings to always "work" 3 or what is more commonly referred to as employment. This is reinforced by the nature of human beings as khalifah on earth who must carry out their duties correctly and earnestly to get the blessing of Allāh in other word, man should work to get the blessing. The sharia considers human life as a worker who certainly will not deviate from the principles and rules with the teachings to always work. ${ }^{4}$ Desires and needs for both one's own needs and those of others can be fulfilled by working. Prosperous life is a life dreamed by all humans, regardless of differences in religion, ethnicity, nation, and others. ${ }^{5}$

Having reached the community welfare, the Indonesian state which is a developing country establishes the Agency Providing Social Security for employment which then will be called as BPJS

\footnotetext{
1 Syarifah Gustiawati Mukri, "Langkah Strategis Optimalisasi Sistem Ekonomi Syariah", Salam: Jurnal Filsafat dan Budaya Hukum, Vol. 1, No. 1 (June, 2014)

2 Adiwarman A. Karim, Ekonomi Mikro Islami, 5th edn (Jakarta: Rajawali Pers, 2016), 25.

3 Yunus Assagaf, "Ketenagakerjaan dalam Konsepsi Syari at Islam", Jurnal Ilmiah AlSyir'ah, Vol. 3, No. 1 (2016), 10.

4 Helly F. Kolondam, Anna Feberina Ginting, Salmin Diego, "Implementasi Program Jaminan Sosial Ketenagakerjaan Di Kota Manado", Jurnal Administrasi Publik, Vol. 3, No. 400 (October, 2016),.10.

5 Nur Kholis, "Kesejahteraan Sosial Di Indonesia Perspektif Ekonomi Islam", Akademika: Jurnal Pemikiran Islam, Vol. 20, No. 2 (October, 2015),. 244.
} 
Employment which is for all Indonesian workers 6 The program is believed to influence national development and increase national productivity commonly referred to as the HDI (Human Development Index). ${ }^{7}$ In addition to influencing national development and increasing national productivity, the protection provided by the government in the form of BPJS is a manifestation of increasing welfare and public services for the Indonesian people fairly and equally. ${ }^{8}$ The protection of labor is actually regulated in chapter IV, Article 9 of Act No. 14 of 1969 concerning the main points of labor before the existence of the BPJS Act. on Article 27 of Act number 3 of 1992 and in the Act Number 24 of 2011 state that the control of the social security program is carried out by the BPJS under the President. ${ }^{9}$

BPJS is actually the responsibility of the state as said by the Prophet "Sayyid al-qawm khâdimukum", meaning that the leader is a servant of the people ${ }^{10}$ which is then used as one of the concepts of Indonesia as stated in the fifth principle of the Pancasila (the Five Principles) "social justice for all indonesian people. So, in article 13 number 1 of the Act number 40 of 2004 concerning the National Social Security System (SJSN) as a continuation of an effort for people's

\footnotetext{
${ }^{6}$ Before the establishment of the BPJS, in Indonesia, there was already an insurance institution to protect the life of the people of Indonesia as stated in the Republic of Indonesia Law Number 40/2004 concerning the National Social Security System and the Republic of Indonesia Law Number 24/2011 concerning the Social Security Organizing Agency. The Act then replaces some existing social security in Indonesia programs, such as the health insurance which was better known as PT Askes Indonesia, which is then changed into the Social Security Organizing Agency (BPJS) Health and employment insurance which is then turned into BPJS Employment, which is directly accountable to the President of the Republic of Indonesia.

7 Jemikan, "Kajian Yuridis Terhadap Pelaksanaan Bpjs Ketenagakerjaan Di Lingkungan Yayasan Perguruan 17 Agustus 1945 Surabaya", DIH Jurnal Ilmu Hukum, Vol. 14, No. 27 (February, 2018), 110.

8 Joyce Jacinta Rares Anggi Chrisye Piteradja, Masje Silija Pangkey, "Implementasi Program Jaminan Hari Tua Di Badan Penyelenggara Jaminan Sosial Ketenagakerjaan Kota Manado", Jurnal Administrasi Publik, Vol. 4, No. 49, (February, 2017), 01.

9 See the Law of the Republic of Indonesia Number 40/2004 concerning the National Social Security System and the law Number 24/2011 concerning the Social Security Organizing Agency

10 Muhammad Syakir Sula, Asuransi Syari'ah (Life and General): Konsep Dan Sistem Operasional, ed. by Harlis Kurniawan, 1st edn (Jakarta: Gema Insani, 2004), 460.
} 
welfare, all employers are required gradually to register their employees as members of the BPJS Employment according to the program followed. ${ }^{11}$ If the employer ignores these rules, sanctions will be imposed according to the Government Regulation number 86 of 2013 concerning the imposition of administrative sanctions for agencies (employers) and workers both as permanent wage earners or non-permanent wage earners (individuals) and premium recipients.

The regulations regarding BPJS are the BPJS Law and the governent regulation number 86/2013. the regulation has not provided clear rules regarding the imposition of sanctions in Article 9 of the government regulation. ${ }^{12}$ On the other hand, not all employers can employ workers permanently, such as a building worker who does not always get fixed contracts while the premium must be paid regularly every month, otherwise, he would be fined for the late payment of $2 \%$ of the premium. This problem also affects non-wage workers as the protection policy covers all residents working in Indonesia. They are are required to become members of the BPJS employment.

As stipulated in law number 40 of 2004 concerning the SJSN in Chapter VI Number 1 of the Social Security Program article 18 concerning the types of social security programs, they include working accident proctection, old age insurance, life insurance, and health insurance. ${ }^{13}$ As a program directly under control of the President of Indonesia as an the agency providing social security, BPJS Employment has added Pension Insurance since July 1, 2015 and so, BPJS covers 5 programs. In addition to health insurance, there are 4 programs in BPJS Employment. ${ }^{14}$ The implementation of the five

\footnotetext{
11 M Arif Hakim, "Analisis Aplikasi Akad Tabarru' Dalam Asuransi Syari'ah : Studi Kasus Pada AJB Bumiputera 1912 Syari'ah Cabang Kudus", Jurnal Muqtasid, V. 3, No. 2, (December, 2012), 11.

12 I Putu Yogi Indra Permana, I Nyoman Suyatna, \& Kadek Sarna, "Implementasi Undang-Undang Nomor 24 Tahun 2011 Tentang Badan Penyelenggara Jaminan Sosial Terkait Pendaftaran Peserta Program Jaminan Sosial Ketenagakerjaan Di Kabupaten Gianyar" Kartha Negara, Vol. 5, No. 2, (April, 2017), 08.

13 See the Sharia Nasional Council of the Indonesian Ulema Council, Fatwa Dewan Syari'ah Nasional-Majelis Ulama Indonesia.

14 Ulfa Luthfiana, "Perlindungan Hukum Terhadap Pekerja/Buruh Penerima Upah Dalam Suatu Perusahaan Yang Tidak Diikutsertakan Dalam Keanggotaan Bpjs
} 
social security programs is expected to be evenly distributed to all Indonesian workers as both in the formal and informal sectors so that basic needs and decent living can be fulfilled.

However, the need for protection through the BPJS Employment for all workers in Indonesia certainly draws attention of Muslims who are the majority of Indonesian population to review from the perspective of sharia economic law. The real example is what happened in Bondowoso, East Java, in which there are residents who quit participating in the BPJS Employment program ${ }^{15}$ because of its services and they thought that the transactions are not in accordance with the sharia economic law. This situation certainly becomes a serious problem that needs to be studied more deeply as the National Sharia Council - Indonesian Ulama Council (DSN-MUI) stipulates the MUI DSN fatwa 21/DSM-MUI /X/2001, because BPJS employment concerns all workers in Indonesia. From the aforementioned background, it is important to analyze the contract of the BPJS employment program in the context of sharia economic law, when the SJSN is implemented to all Indonesian people regardless of class, religion, and ethnicity.

\section{Research Method}

This study applies normative legal research methods or library research that examines documents such as legislation and legal theories ${ }^{16}$ relating to labor social security. This method is applied to analyze BPJS Employment more deeply. The data sources used are secondary data that have been available from existing data, namely the 1945 Constitution, Laws, Government Regulations, Presidential Regulations, Presidential Decrees, BPJS Employment Regulations, DSN-MUI Fatwa, Pancasila, and books. In addition to the secondary data sources, it is necessary to have material that explains or informs the data sources, namely tertiary data sources such as legal language dictionaries, encyclopedias, magazines, bibliographies, mass media both printed and electronic media.

Ketenagakerjaan Ditinjau Dari Undang-Undang Nomor 24 Tahun 2011 Tentang BPJS", Hukum Progresif, Vol. 10 No. 1, (June, 2016), 1661.

15 Interview with Abdul Halim and Mursidi, residents from Sumber Anom, Tamanan district, Bondowoso on Monday November 5, 2018

16 Peter Mahmud Marzuki, Penelitian Hukum, (Jakarta: Kencana, 2010), 35. 
Data collection technique applied in this study is interview which is done directly or indirectly ${ }^{17}$ (by utilizing sophisticated electronics, respondents of this study do not have to be visited at work or where they live). Interviews done by the the researcher in a structured and unstructured way. ${ }^{18}$ However, the researcher unstructured interviews are done more often to find specific problems in asking for ideas or opinions from respondents related to BPJS Employment in providing social security for workers. The interviews are done to the relevant BPJS Employment personels, members of the BPJS Employment and non-members of the BPJS Employment. The collected data are then analyzed descriptively ${ }^{19}$, which are expected to answer the problem comprehensively. Which is expected to answer the problem comprehensively. Another result expected from this research is that it can answer the problem or become the right solution that can be applied in real life.

\section{Discussion}

The word transaction is inseparable from human life, in their daily lives. This is because, transactions are buying and selling good activities ${ }^{20}$ which are needed by humans in the economic sphere. The economic activities would be safe and stable with the existence of an agreement (contract) as a basis or law Therefore, every society, especially in Indonesia, with a Muslim majority, should be able to understand it so that every transaction done in accordance with sharia. ${ }^{21}$ This is because a contract is an important part in a transaction and need to be undertaken in carrying out all activities to gain the blessing of Allāh. The problem is that the perceptions of the government and the people are not always in line with in everyday life. ${ }^{22}$ Muslims who want to be able to carry out the religious laws set

17 Sugiyono, Metode Penelitian Kualitatif, (Bandung: Alfabeta, 2017), 111.

18 John W. Creswell, Research Design: Pendekatan Metode Kualitatif, Kuantitatif, dan Campuran, (Yogyakarta: Penerbit Pustaka Pelajar, 2018), 276-277.

19 Achmad Fawaid, Pengantar Penulisan Akademik, (Yogyakarta: Pustaka Pelajar, 2016), 225.

20 Pius Partanto, \& M. Dahlan Barry, Kamus Ilmiyah Populer, (Surabaya: Penerbit Arkola Surabaya, 2001), 20.

21 FORDEBI \& ADESy, Ekonomi Dan Bisnis Islam: Seri Konsep Dan Aplikasi Ekonomi dan Bisnis Islam, ed. by Ahim Abdurahim et al., 1st edn (Jakarta: Rajawali Pers, 2016), 169. ${ }^{22}$ Nur Kholis, "Kesejahteraan Sosial Di Indonesia Perspektif Ekonomi Islam".,255. 
in the Qur'an and Sunnah (in this case the sharia economic law) should be more careful, especially, with the increasingly rapid technological progress which may overrides the existence of halâl and haram (legitimate and illegitimate) transactions in the context of Islamic economic law.

In syarî'ah economic law, there is a contract that underlies a transaction. ${ }^{23}$ In Arabic, the contract is termed as "al-'aqd" which means agreement or bound. In figh (islamic jurisprudence) terminology, contract means ijâb qabûl (offer and acceptace) which are in accordance to sharia done by two or more parties with the stipulated provisions. ${ }^{24}$ Veithzal Rivai and Andi Buchari say that a contract (bound, connection and agreement) is a statement about a bound desired by the first party with a statement of acceptance from the second party which is often referred to as ijâb qabul without deviating from sharia law. ${ }^{25}$ So, it can be understood that a contract is a statement of $i j a ̂ b$ qab $\hat{u} l$ (offer and acceptace) with an agreement in a transaction done by two or more people in accordance with sharia law. ${ }^{26}$

\section{The View of Syarîa Economic Law on the Contract of BPJS for Employment Program}

To realize the welfare of the people of Indonesia, the state provides rights for workers to social security 27 regarding the risks

\footnotetext{
${ }_{23} \mathrm{Mu}$ 'amalah is interaction and communication amongst human beings related to assets and economic or business activities. see Imam mustofa, Fiqih Mu'amalah Kontemporer, (Jakarta: Rajawali Pers, 2016), 6.

24 Nasrun Haroen, Figh Muamalah, (Jakarta: Penerbit Gaya Media Pratama, 2007), 97.

25 Veithzal Rivai \& Andi Buchari, Islamic Ekonomics (Ekonomi Syari'ah Bukan Opsi, Tetapi Solusi), (Jakarta: Bumi Aksara, 2009), 344.

26 There are several pillars of contract that must be fulfilled so that the contract is done in accordance with Islam. As has been set by number of fiqh scholars, namely: a) Ijâb qabûl, b) the parties concerned, and c) The object of the contract. See Nasrun Haroen, Fiqh Muamalah.,97.

27 In the 1945 Constitution article $28 \mathrm{H}$ paragraph 3, it is emphasized that everyone has the right to obtain social security for himself as a dignified human being. Likewise, in paragraph 2 of the 1945 Constitution, it is stated that social security has been developed for all Indonesian people who less fortunate. See Matias Siagian, "Tingkat Kepuasan Karyawan Perusahaan Swasta dalam Pelayanan Jaminan Sosial Tenaga Kerja (Jamsostek)", Kesmas: Jurnal Kesehatan Masyarakat Nasional, Vol. 7, No. 5, (December, 2012), 200.
} 
that will be taken or have been taken by workers at work. Social security is one of the needs and hopes of both poor and rich communities to overcome the risks occur, such as accidents, death, being fired and others. ${ }^{28}$ This is based on labor rights according to Chaudry quoted by Sri Herianingrum and Tika Widiastuti which include: ${ }^{29}$ First, workers must get health care or medical treatment costs from the employer which will then be refined by the government if they are sick at that time. Second, employers should provide provisions for pension funds for elderly workers from the contributions of both (workers and employers) as aid funds. Third, to stabilize the domestic wage level, the employer must provide security to workers when they no longger work (stop working). Fourth, when an accident occurs at work, the employer must give compensation for the workers adequately. Fifth, the availability of accommodation must be sufficient so that the health of the workforce and efficiency of work are at maximum level.

Based on the labor rights explained above, the protection is done by the government for the future of the people by deducting a portion of wages during work monthly, quarterly, or adjusted periods. ${ }^{30}$ The four social security programs ${ }^{31}$ from the government are in the form of Work Accident Protection (JKK), Death Insurance (JKM), Old Age Insurance (JHT), and also Pension Insurance (JP) which are under the program of BPJS for employment. ${ }^{32}$

\footnotetext{
28 Ahmad Nizar Shihab, "Hadirnya Negara Di Tengah Rakyatnya Pasca Lahirnya Undang-Undang Nomor 24 Tahun 2011 Tentang Badan Penyelenggara Jaminan Sosial (The Presence Of The State Among People After The Declaration Of Law Number 24 Year 2011 Concerning Social Security Administeri", Jurnal Legislasi Indonesia, Vol. 9, No. 2, (2018), 177.

29 FORDEBI \& ADESy, Ekonomi Dan Bisnis Islam: Seri Konsep Dan Aplikasi Ekonomi dan Bisnis Islam, 231-232.

30 Adiwarman A. Karim, Fikih Ekonomi Islam, ed. by Abu Umar Basyir, IV (Jakarta: Dârul Haq, 2013), 274.

31 These four programs can be enjoyed by wages recipients whose location, working hours and total income are fixed, in contrast to the lower middle class people who do not have workplace, working hours, fixed income and uncertain business continuity who is called Non-Recipient Wages (BPU). see www.bpjsketenagakerjaan.go.id Retrieved January 10, 2019.

32 The BPJS employment is engaged in social insurance which was previously known as PT Jamsostek (Persero) as stated in the Law No. 40/2004 concerning national social security security system and the Law No. 24/2011 on BPJS.
} 


\section{a. Work Accident Protection Program (JKK)}

Risk at work cannot be anticipated or interpreted when it occurs. All organizations must have equip themselves with both a defense or action to avoid dangers that might occur, such as protection tools, supervisory actions, procedures and regulations applied in the organization. ${ }^{33}$ In this case, workers have been registered with the Social Security Agency (BPJS) for employment at the outset to work by deducting a portion of the workers' salary to pay contributions as premium for future risks. As stated in the Law of the Republic of Indonesia Number 40 /2004 concerning National Social Security System chapter IV National Social Security Council, article 17 number (2) Every employer is obliged to collect contributions from workers, in addition to his contribution which is his obligation and pay the contributions to BPJS periodically, dan pada No. (3) and in number (3) The amount of the premium is set for each type of program on a regular basis in accordance with the development of social, economy and decent basic needs of life.

The danger at work can occur when leaving for work, going home from work, or when working or diseases found in the work environment. As stated in the law of the Republic of Indonesia number 13/2003 concerning employment in article 86 paragraph (2) that "Work safety and health efforts are intended to provide security to workers when there is a risk or danger while working with treatment and rehabilitation" ${ }^{34}$ In this case, the JKK program applies so that participants get protection in the form of cash compensation or healthcare as protection against the risks they have experienced. ${ }^{35}$

\footnotetext{
33 Priska Yunita Maria Carolina Tolala, Vanda Doda, Johan Josephus, "Implementasi Layanan Jaminan Kecelakaan Kerja BPJS Pada Tenaga Kerja Bongkar Muat Di Pelabuhan Laut Manado", Paradigma, Vol. 4, No. 3, (2016), 47.

34 See Himpunan Lengkap Undang-Undang Ketenagakerjaan, Ed. 1 (Jogjakarta: Buku Biru, 2013),167.

35 Suparwi Endang Setiowati, Suharno, "Pelaksanaan Bpjs Ketenagakerjaan Bagi Karyawan Di Kota Surakarta Pada Kantor Cabang Bpjs Ketenagakerjaan Kota Surakarta", Seminar Nasional Perlindungan Hukum Terhadap Tenaga Kesehatan Dan Pasien Dalam Perspektif UU No. 36 Tahun 2014', 2017.,157-167.
} 
The amount of premium of the JKK program ${ }^{36}$ is divided into several groups based on how much risk taken by participants at work, namely: 1) Group I: $0.24 \%$ of monthly wages 2 ) Group II: $0.54 \%$ of the wages 3 ) Group III: $0.89 \%$ of monthly wages 4) Group IV: 1.27 the wages 5) Group V: $1.74 \%$ of wages per month. ${ }^{37}$ The basis of the social security program is an effort to help each other amongst those who are registered as members of the BPJS for Employment for the welfare of other participants. 38 Therefore, all fellow workers are encouraged to maintain the culture which is the characteristic of Indonesia, namely cooperation, and mutual assistance, to help those in need. As Allāh said in Q.S al-Maidah 5: 2 which means:

“.... And cooperate in righteousness and piety, but do not cooperate in sin and aggression..."

The word help in this verse is in terms of virtue or piety, that is, all forms and kinds of things that bring benefit to the world and or in the hereafter, things that do not lead to disaster even to people who are not believers. ${ }^{39}$ It is clear that mutual help in Islam known as ta' $\hat{a} w u n^{40}$ is highly recommended and required in this life, such as helping our brothers to fulfill their needs or alleviating burden of their life and making them prosperous. ${ }^{41}$ In the context of $t a^{\prime} \hat{a} w u n, M$. Arif Hakim states that in guaranteeing the welfare of the community, which is known as insurance, in Islamic law ta'âwun constitutes one of the main principles of mu âmalah (interaction and transaction). This is because, with mutual help those in need would be assisted by the

\footnotetext{
36 Payment of premiums in the work accident insurance program is fully borne by the employer. Workers do not have to pay their own premiums that are deferred to BPJS Employment because employers must be responsible for the safety of their workers. 37 See the complete set of laobr law. 203.

38 Abdul Manan, Hukum Ekonomi Syari'ah: Dalam Perspektif Kewenangan Peradilan Agama, 1st edn (Jakarta: Kencana Prenada Media Group, 2012), 238.

${ }_{39}$ M. Quraish Shihab, Taafsir Al-Misbah (Pesan, Kesan Dan Keserasian Al-Qur'an) Vol. III (Jakarta: Lentera Hati, 2002), 10.

$40 \mathrm{Ta} \hat{a} \mathbf{w} w \mathrm{n}$ is a form of cooperation on lawful way in gaining benefits permitted by Islamic law.

41 Surya Vandiantara, "Tinjauan Hukum Islam Tehadap Proses Pengelolaan Dan Konsep Investasi Dana Premi BPJS Ketenagakerjaan", Jurnal Balance, Vol. XIV, No. 1, (January, 2017), 119.
} 
wealthy in order to be able to get life welfare through tabarru' fund mechanism. ${ }^{42}$

In terms of contract, it is clear that the concept of JKK includes the tabarru' contract, which is all forms of contract based on goodness in order to help each other and not for commercial purposes. The aim to do the tabarru' is an alternative way that is permissible according to sharia to avoid gharar practices. Tabarru's premium paid is nothing but a donation given to other participants who are in need. ${ }^{43}$

\section{b. Death Inssurance Program (JKM)}

The death insurance program, hereinafter referred to as JKM, provides benefits in the form of cash for active worker participants who die not because of accidents at work. ${ }^{44}$ The funds of the JKM program is a benefit for heirs to ease the burden on the family and heirs in the form of both cash compensation and compensation for funeral expenses. ${ }^{45}$

The employer bears premium of $0.3 \%$ for life insurance ${ }^{46}$ with death insurance claims given including: 1) Compensation in the form of cash in the amount of Rp16,200,000.00; 2) Periodic compensation for 2 years, as much as $24 \times$ Rp. 200,000.00 = Rp. 4,800,000.00; 3) Funeral expenses of Rp. 3,000,000 4) Scholarship for one child for participants

42 M. Arif Hakim, "Analisis Aplikasi Akad Tabarru' Dalam Asuransi Syari'ah: Studi Kasus Pada AJB Bumiputera 1912 Syari'ah Cabang Kudus", Jurnal Muqtasid, Vol. 3, No. 2, (December, 2012), 240.

43 Ulfa Luthfiana, "Perlindungan Hukum Terhadap Pekerja/Buruh Penerima Upah Dalam Suatu Perusahaan Yang Tidak Diikutsertakan Dalam Keanggotaan Bpjs Ketenagakerjaan Ditinjau Dari Undang-Undang Nomor 24 Tahun 2011 Tentang BPJS".,245.

44 The death insurance program only applies to participants who die not due to accidents at work. However, participants who die due to accidents at work are coverd by work accident insurance program (JKK).

45 See www.bpjsketenagakerjaan.go.id/ Program Jaminan Kematian, retrieved January 10, 2019.

46 The statement has been stated in article 46 of the Law number 40/2004 concerning the National Social Security System. The amount of premium of the death insurance for the wage recipient participant (fixed salary worker) is determined based on a certain percentage of wages or income and the amount of premium of the death insurance for non-wage participants (non-fixed income workers) is determined based on a certain amount paid by the participants. The provisions referred to are further stipulated in Government Regulations. 
who have reached minimum of 5 (five) years of premium up to Rp.12,000,000.00.

The total amount of JKM benefits received by the family and the heirs of the participants are IDR 36,000,000.00.47 With such amount of funds, it is expected that it could help the family and the heirs. The concept of al-ta'min al-ta'âwunî, namely $t a^{\prime} \hat{a} w u n$ in the contract of tabarru' as stated in the Qur'an to protect each other can be found not only in the accident at work insurance, but also in the death insurance program. ${ }^{48}$ In Islamic economics, the JKK and JKM programs are included in the type of takâful insurance because participants do not intend to get benefits from other participants but are equally willing to cover up the shortcomings that they have experienced, that is, to cope with disaster together and to help face dangers. ${ }^{49}$

\section{c. Old Age Insurance (JHT)}

Old Age Insurance, abbreviated as JHT, aims to give protection at time of termination of employment, retirement age ${ }^{50}$, having permanent total disability (disability that causes a person unable to work or return to work) and or death. ${ }^{51}$ participants still receive wages taken from funds that have been saved when they were working. ${ }^{52}$ This is as stated in the law of the Republic of Indonesia number 40 /2004, chapter VI, part 4, point 2 on old age insurance. The JHT program is one unit with JKK which is required for each participant with a saving system. While the JKK program aims at anticipation of treatment when a risk occurs, JHT program is intended

47 See https://www.bpjsketenagakerjaan.go.id/page/Program-Jaminan-Kematian (JKM).html, retrieved January 10, 2019

48 Zaky Al Hamzah, "BPJS dan Jaminan Sosial syari'ah", Republika, January17, 2014: https://republika.co.id/berita/koran/news-update/14/01/16/mzi35n-bpjs-danjaminan-sosial-syariah, retrieved January 11, 2019

49 Adiwarman A. Karim, Fikih Ekonomi Islam.,273-283.

50 Retiring person is someone who no longger works, aged around 57 years old. This old age insurance program also applies to workers who stop working (to a company) even though they have not reached age to retire.

51 See the Act. No. 40/2004 on National Security System and the Act. no. 24/2011 on the Social Security Agency. 20. By submitting a claim to the BPJS Employment, the participant can withdraw funds while he was working

52 By submitting a claim to the BPJS Employment, the participant can withdraw funds while he is working. 
to anticipate future funding needs when participants no longer work. 53

This savings system is not entirely from labor contributions, but also from the contributions of the employers and also claims that would be received by workers will also increase due to additional funds from the profit sharing development. ${ }^{54}$ The premium scheme is: $2 \%$ paid by participants and $3.7 \%$ paid by the employer with total amount up to $5.7 \%$ of wages. 55 The premiun of the JHT program is borne jointly by the employer and workers, because in addition to old age savings for workers, it would be also a reward for working in the company for years. ${ }^{56}$ So, savings in the JHT program will remain, which in this case, in the sharia economics is known as mudlârabah contract. ${ }^{57}$

The management and investment of funds in the BPJS for employment program have the same concept as mudlârabah musytarakah contract, namely, the premium of the BPJS for employment as mudlârib and those of the participants as shâhib al-mâl are put together. ${ }^{58}$ Thus, the management and investment is the same as mudlârabah musytarakah contract. ${ }^{99}$ However, the BPJS for employment has some differences from mudlârabah musytarakah contract in that the former does not make itself as a mudlârib and the investment share of BPJS is not the same as the provisions of mudlârabah musytarakah contract because BPJS Employment has its own provisions stated in the BPJS law itself.

53 Yunus Assagaf, "Ketenagakerjaan dalam Konsepsi Syari at Islam", 27.

54 BPJS Employment funds that will be claimed by workers later when they no longger work will not expire. Participants who have died, their old-age insurance will be inherited to their family or to those on their will.

55 Suparwi Endang Setiowati, Suharno, "Pelaksanaan BPJS Ketenagakerjaan Bagi Karyawan Di Kota Surakarta Pada Kantor Cabang BPJS Ketenagakerjaan Kota Surakarta". 163.

56 Yunus Assagaf, "Ketenagakerjaan dalam Konsepsi Syari`at Islam", 03.

57 Joyce Jacinta Rares Anggi Chrisye Piteradja, Masje Silija Pangkey, "Implementasi Program Jaminan Hari Tua Di Badan Penyelenggara Jaminan Sosial Ketenagakerjaan Kota Manado".,128.

58 Fatwa of National Sharia Council of MUI No. 21/DSN-MUI/X/2001

59 Surya Vandiantara, "Tinjauan Hukum Islam Tehadap Proses Pengelolaan Dan Konsep Investasi Dana Premi BPJS Ketenagakerjaan",128-129. 


\section{d. Pension Insurance Program (JP)}

In essence, humans have limitations in all things. Just like working, at age of 57 years, the body no longer works properly and efficiently. For the old age security, the government provide pension insurance program which was later called JP 60 as savings that would be needed in the future. ${ }^{61}$

From the above assumptions, it shows that JP aims to protect participants or heirs due to death of the participants. ${ }^{62}$ This is because, if the participant dies during the agreement period, the heirs will receive funds that have been paid in advance by participants who will also get benefits from the investment of this JP program fund. 63 Pension insurance is also in the form of cash obtained as: ${ }^{64} 1$ ) Old age pension, obtained by workers after retirement during his life. 2) Disability pension, obtained by permanent disability workers due to accident or illness before reaching retirement age until death 3) Widow/widower pension, obtained by widows/widowers heirs of workers until they remarriage or death 4) Pension for children, obtained by children of heirs until they reach the age of 23 years or

60 See Ari Hernawan, Keberadaan Uang Pesangon dalam Pemutusan Hubungan Kerja Demi Hukum di Perusahaan yang Sudah Menyelenggarakan Program Jaminan Pensiun", Kertha Patrika: Jurnal Ilmiah Fakultas Hukum Universitas Udayana, Vol. 38, No. 1, (January-April, 2016), 4. Government contributions to pension benefits are managed by an individual protection system related to income. It is stated in article 39 of the SJSN law that pension insurance is to maintain a decent life for workers whose income is reduced because they have reached retirement age.

61 This Pension insurance program is an additional program that can be operated on July 1, 2015 which follows one and a half years later than the other three insurance programs, namely JKK, JKM and JHT according to the National Social Security System. See Siti Kunarti, Tedi Sudrajat, Sri Wahyu Handayani, "Transformation of Social Security Administrative Body (BPJS) within Social Security Reform in Indonesia", SHS Web of Conferences, Vol. 54, P. 03017, (2018), 04.

62 Indonesia as a country that wants to strive for the welfare of its people try to provide protection for workers and their families. The JP program serves as compensation to the families of workers left behind to ease the burden of the funds needed to take care for participants who have died. In addition, JP is also a form of appreciation and motivation for workers throughout the Indonesian homeland without any exceptions, reagrdless of their race, ethnicity, gender, and others.

63 Abdul Manan, Hukum Ekonomi Syariah: Dalam Perspektif Kewenangan Peradilan Agama, 274.

64 See the Law No. 40/2004 concerning National Social Security System and the Law No. 24/2011 concerning the Social Security Agency, 13-18. 
until they get marriage 5) Pension of parents, obtained by parents of heirs of unmarried participants according to the provisions of the legislation.

It can be said that this program is a transition from inheritance theory. In Islam, the giving or transfer of ownership of a person who has died to his family or his heirs is regulated in a contract of inheritance. The provisions of fair and wise inheritance is explained in a great detail in the Qur'an as can be found in Q.S al-Nisa 4: 11-12 and 176. A French sociologist, Dr. Gustave Lebon said that what are outlined in the Qur'an are very fair and objective, because Islam also gives inheritance rights to a woman, things that had never been found in other laws. 65

From the discussion of the program above, it can be ascertained that the contract in BPJS for employment does not deviate from the sharia economic law, as stipulated in fatwa by the National Sharia Council of MUI (Indonesian Ulama Council) that the contract used in sharia insurance is a tabarru' contract. in the JKK and JKM programs, the fund is a grant from participants that is used to help other participants affected by the disaster, managed by a company. Meanwhile, the JHT program is an investment program that has the same concept as a mudlârabah contract as stated in the fatwa of the National Syaria Council of MUI who calls it as tijarah contract (funds invested in BPJS Employment in which JHT participants can claim at any time with agreed conditions). The JP program (pension insurance) can be catagorized as investment funds which can then be changed to the type of tabarru' contract. ${ }^{66}$ In this JP program, a worker must at least become a BPJS employment participant for 15 years, then he can give his mudlârabah funds to the heirs according to the inheritance law in mu'amalah.

This is also confirmed in the SJSN program which is held based on the principles: 1 . Mutual cooperation (helping each other amongst participants who are in need); 2 . Nonprofits (trust funds, not intended to seek profits, the profits gained and budget surpluses will be

65 FORDEBI \& ADESy, Ekonomi Dan Bisnis Islam: Seri Konsep Dan Aplikasi Ekonomi dan Bisnis Islam,.391.

66 Fatwa of the National Sharia council No. 21/DSN-MUI/X/2001 on the general guidelines of sharia insurance. 
utilized as much as possible for the benefit of participants); 3 . Openness (prudence, accountability, efficiency and effectiveness); 4. Caution; 5. Accountability; 6. Portability (the active period of participations is unchanged by changing workplace); 7. Participation is compulsory (to cover all sectors of employment in Indonesia without any differences); 8. Trust funds (the funds are very well managed in order to optimize these funds for the welfare of participants); and 9. The profits gained from social security funds are intended as a whole for the development of the program funds which will then be used for the interests of the participants (from participants and will return to the participants because of the interests of the participants). ${ }^{67}$

However, the rights for the social security for workers which are expected to be evenly distributed throughout Indonesia still face constraints. This agenda calls the government's attention to resolve it. for example, in Madura island (Pamekasan and its surroundings), there are still many workers who are not registered as permanent members of the BPJS Employment. ${ }^{68}$ This is because either the socialization constraints in which it has not yet spreaded out throught the island or the BPJS employment constraints, in which it has not scheduled the socialization to rural areas that actually have workers with fixed wages or those with not fixed wages. Unlike the Bondowoso area, in which although the average population there works in mountainous areas, the permanent membership of the BPJS Employment is almost evenly spread out through out the areas. ${ }^{69}$

In Islamic law, social security is legal or lawful. This view is expressed by 'Abd al-Wahhab Khallaf, Muhammad Yusuf Musa, 'Abd al-Rahman Isa, Mustafa Ahmad Zarqa, and Muhammad Nejatullah Siddiqie. Some reasons for this view are: 1) In the Qur'an

67 See See the Law No. 40/2004 concerning National Social Security Systemty Agency chapter II concerning Principles, Objectives, and Implementation, Article 4

68 Interview with Fariqi Wahdy, a teacher at Madrasah Ibtidaiyah Islamiyah Ambat Tlanakan Pamekasan, Jasuli (from Ambat, Tlanakan, Pamekasan), Munaser (from Taro'an, Tlanakan, Pamekasan) and Abdul Basit (from Palengaan, Pamekasan) who is a construction worker. The interview is done from Tuesday January 15, 2019 to Monday January 21, 2019

69 Interview with Meila Rosanti, marketing director and TI BPJS employment in Bondowoso branch, it is done on Friday November 9, 2018 
and Hadith there are no provisions regarding the prohibition of social security 2) There is willingness amongst participants 3) The benefits are greater than the disadvantages 4 ) The social security is based on mudlârabah contract, namely profit sharing 5) The social security is categorized as cooperative 6) It is analogous to pension funds.

According to Muhammad Abu Zahrah, social security program is allowed on condition that it is for social purposes and not for commercial ones. Therefore, social security program does not contain elements that are prohibited by sharia law or sharia economic law and is carried out only for the benefit of society. In contrast to commercial insurance, in which can be found things that are not in accordance with sharia law. ${ }^{70}$ Accordingly, the largest organizations in Indonesia, Nahdlatul Ulama (NU), allows social insurance on condition that social insurance is based on ta'âwun as stated in one of its deliberations. NU allows not only social security but also life insurance if it meets the requirements, which are: containing savings, there is a tabarru' agreement which only applies to virtues, investment in sectors that are permissible under Islamic law, funding claims can be done at any time when participants are in need without waiting for due date, and premium payments that are not paid off at a predetermined time will be considered a debt that can be repaid on subsequent provisions of the premium payments, and the account will remain valid without closure or forfeited funds. ${ }^{71}$

To ensure the premium from an agency that has registered its workers as a BPJS Employment participant is paid on time, it is necessary to impose sanctions as a form of assertiveness in labor protection. However, for the less fortunate, the premium of the social security program is paid by the government as stated in the law of the Republic of Indonesia number 40/2004 concerning the National Social Security System, chapter V concerning Participation and Contributions in Article 17 Number 4. With regard to the imposition of applicable sanctions for those who cannot pay the premium on time, there are parties who raise objection to the provision. They are

70 Abdul Manan, Hukum Ekonomi Syariah: Dalam Perspektif Kewenangan Peradilan Agama, 253.

${ }^{71}$ Husni Mubarrak, "Kontroversi Asuransi Di Indonesia: Telaah Fatwa Majelis Ulama Indoneisa (MUI) Tentang Badan Penyelenggaraan Jaminan Sosial (BPJS)", Tsaqafah, Vol. 12, No. 1, (May, 2016), 116. 
mostly companies that do not have a fixed time in hiring workers (building, furniture, travel) or do not have fixed income to pay the workers (such as shopkeepers and others).

Meanwhile, according to Yusuf al-Qardlawi in his Fatwa on the Society and $m u^{\prime}$ âmalah number 13 , it said that in imposing a fine for late payments according to al-Khaththab from the Mâliki school, some contemporary scholars argue that it is permissible for those who owe and are able to pay but they postpone to do so as promised, the fine is considered alms. The fine is then given to those who are in need as charity. ${ }^{72}$ So, for those who cannot afford or are not able to pay the premium, there will be dispensation in the from of either an extended period or downsizing premiums that must be paid off.

From the discussion above, it proves that BPJS employment which is run in the social sphere does not deviate from sharia economic law in terms of the contract because it contains virtues for the welfare of the society. There are only a few things that need to be considered such as premium paid monthly, there should have dispensation for certain members.

\section{Conclusion}

The results of the Research on the contract of the Social Security Agency (BPJS) for employmen in the context of sharia economic law show that this study produces several things that could add knowledge and answer apprehension of Indonesian people, especially Muslims. In general, the BPJS Employment programs do not deviate from the sharia economic law becaus the contract of the program contains virtue that benefits most of the workers, especially the BPJS Employment participants, such as the tabarru' contract, ta' âwun which applies only to virtue. There is also savings program that has the same concept as the mudlârabah musytarakah contract and inheritance contract. It is in accordance with the fatwa of the National Sharia Council No. 21/DSN-MUI/X/2001 concerning general guidelines for sharia insurance.

\footnotetext{
72 Yusuf al-Qardlawi, Fatwa-Fatwa Kontemporer Vol. 3, ed. by Abdul Hayyie Al-Kattani et al. (Jakarta: Gema Insani Press, 2002)., 534.
} 
The Contract of the Social Security Agency for Employment

\section{Bibliography}

Al Hamzah, Z. "BPJS dan Jaminan Sosial syarî'ah", Republika,17 January 2014: https://republika.co.id/berita/koran/newsupdate/14/01/16/mzi35n-bpjs-dan-jaminan-sosial-syariah (retrieved January 11 2019).

Al-Qardhawi, Y. Fatwa-Fatwa Kontemporer Vol. 3. Translator: Abdul Hayyie al-Kattani et al. Edition. 1. Jakarta: Gema Insani Press, 2002.

Assagaf, Y. "Ketenagakerjaan Dalam Konsepsi Syari at Islam”. Jurnal Ilmiah Al-Syir'ah, Vol. 3, No. 1 (2016).

Fatwa Dewan Syari'ah Nasional No. 21/DSN-MUI/X/2001 tentang pedoman umum asuransi syari'ah.

Fawaid, A. Pengantar Penulisan Akademik. Yogyakarta: Pustaka Pelajar, 2016.

FORDEBI, \& ADESy. Ekonomi dan Bisnis Islam: Seri konsep dan aplikasi Ekonomi dan Bisnis Islam. Jakarta: Rajawali Pers, 2016.

Ginting, A. F., Dengo, S., Kolondam, H. F. “Implementasi Program Jaminan Sosial Ketenagakerjaan Di Kota Manado". Jurnal Administrasi Publik, Vol. 3, No. 400 (October, 2016).

Hakim, M. A. "Analisis Aplikasi Akad Tabarru' Dalam Asuransi Syarî'ah: Studi Kasus Pada AJB Bumiputera 1912 Syarî'ah Cabang Kudus". Jurnal Muqtasid, Vol. 3, No. 2 (December, 2012).

Haroen, N. Fiqh Muamalah. Edition. 2. Jakarta: Penerbit Gaya Media Pratama, 2007.

Hernawan, A. "Keberadaan Uang Pesangon dalam Pemutusan Hubungan Kerja Demi Hukum di Perusahaan yang Sudah Menyelenggarakan Program Jaminan Pensiun", Kertha Patrika: Jurnal Ilmiah Fakultas Hukum Universitas Udayana, Vol. 38, No. 1, (January-April, 2016)

https://www.bpjsketenagakerjaan.go.id/page/Program-JaminanKematian (JKM).html ) retrieved January 10, 2019).

Jemikan. “Kajian Yuridis Terhadap Pelaksanaan Bpjs Ketenagakerjaan Di Lingkungan Yayasan Perguruan 17 Agustus 1945 Surabaya". DiH Jurnal Ilmu Hukum, Vol. 14, No. 27, (Februari, 2018). https:/ / doi.org/10.5281/zenodo.1188352.Jay, 27(14), 109-120

Karim, A. A. Ekonomi Mikro Islami. Ed. 8. Ed. 5. Jakarta: Rajawali Pers, 2016. 
Bahjatul Imaniyah

------. Fikih Ekonomi Islam. Translator. Abu Umar Basyir, IV. Jakarta: Darul Haq, 2013.

Kholis, N. "Kesejahteraan Sosial Di Indonesia Perspektif Ekonomi Islam". Akademika, Vol. 20, No. 2, (October, 2015).

Luthfiana, U. "Perlindungan Hukum Terhadap Pekerja/Buruh Penerima Upah Dalam Suatu Perusahaan Yang Tidak Diikutsertakan Dalam Keanggotaan Bpjs Ketenagakerjaan Ditinjau Dari Undang-Undang No. 24 Tahun 2011 Tentang BPJS". Hukum Progresif, Vol. X, No. 1, (June, 2016)

Manan, A. Hukum Ekonomi Syarî'ah dalam Perspektif Kewenangan Peradilan Agama. Jakarta: Kencana Prenada Group, 2012.

Mubarrak, H. "Kontroversi Asuransi Di Indonesia: Telaah Fatwa Majelis Ulama Indoneisa (MUI) Tentang Badan Penyelenggaraan Jaminan Sosial (BPJS)". Tsaqafah, Vol. 12, No. 1, (May, 2016).

Mukri, S. G. "Langkah Strategis Optimalisasi Sistem Ekonomi Syariah", Salam: Jurnal Filsafat dan Budaya Hukum, Vol. 1, No. 1, (June, 2014).

Mustofa, I. Fiqih Mu'amalah Kontemporer. Jakarta: Rajawali Pers, 2016.

Partanto, P. A., Barry, A., M. Dahlan. Kamus Ilmiah Populer. Surabaya: Penerbit Arkola Surabaya, 2001.

Permana, I. P. Y. I., Suyatna, I. N., \& Sarna., K. 2017. “Implementasi Undang-Undang No. 24 Tahun 2011 Tentang Badan Penyelenggara Jaminan Sosial Terkait Pendaftaran Peserta Program Jaminan Sosial Ketenagakerjaan Di Kabupaten Gianyar". Jurnal, Vol. 5, No. 2, (April, 2017).

Piteradja., A. C., Pangkey., M. S., \& Rares., J. J. 2017. “Implementasi Program Jaminan Hari Tua Di Badan Penyelenggara Jaminan Sosial Ketenagakerjaan Kota Manado". Jurnal Administrasi Publik, Vol. 4, No. 49, (February, 2017).

Rivai, V., Buchari, A. Islamic Economics: Ekonomi Syarî'ah bukan Opsi, Tetapi Solusi. Jakarta: PT Bumi Aksara, 2009.

Setiowato, E., SuharNo., \& Suparwi. "Pelaksanaan BPJS Ketenagakerjaan Bagi Karyawan Di Kota Surakarta Pada Kantor Cabang BPJS Ketenagakerjaan Kota Surakarta". Seminar Nasional Perlindungan Hukum Terhadap Tenaga Kesehatan Dan Pasien Dalam Perspektif UU No. 36 Tahun 2014, (2017). 
Shihab, A. N. "Hadirnya Negara Di Tengah Rakyatnya Pasca Lahirnya Undang-Undang No. 24 Tahun 2011 Tentang Badan Penyelenggara Jaminan Sosial (The Presence Of The State Among People After The Declaration Of Law Number 24 Year 2011 Concerning Social Security Administeri". Jurnal Legislasi Indonesia, Vol. 9, No. 2, (2012)

Shihab, M. Q. Tafsir Al-Misbah: Pesan, Kesan dan Keserasian Al-Qur'an. Cet. IX. Vol. 3. Jakarta: Lentera Hati, 2012.

Siagian, M. “Tingkat Kepuasan Karyawan Perusahaan Swasta dalam Pelayanan Jaminan Sosial Tenaga Kerja (Jamsostek)", Kesmas: Jurnal Kesehatan Masyarakat Nasional, Vol. 7, No. 5, (December, 2012).

Siti Kunarti, Tedi Sudrajat, Sri Wahyu Handayani, "Transformation of Social Security Administrative Body (BPJS) within Social Security Reform in Indonesia", SHS Web of Conferences, Vol. 54, P. 03017, (2018).

Sula, M. S. Asuransi Syarî'ah (Life and General): Konsep Dan Sistem Operasional. Jakarta: Gema Insani Press, 2004.

tn. Himpunan Lengkap Undang-Undang Ketenagakerjaan. Ed. 1. Jogjakarta: Buku Biru, 2013.

Tolala, P. Y. M. C., Doda, V., \& Josephus, J. “Implementasi Layanan Jaminan Kecelakaan Kerja BPJS Pada Tenaga Kerja Bongkar Muat Di Pelabuhan Laut Manado". Jurnal Paradigma, Vol. 4, No. 3, (2016).

Undang-Undang Republik Indonesia No. 24 Tahun 2011 Tentang Badan Penyelenggara Jaminan Sosial

Undang-Undang Republik Indonesia No. 40 Tahun 2004 Tentang Sistem Jaminan Sosial Nasional

Vandiantara, S. "Tinjauan Hukum Islam Tehadap Proses Pengelolaan Dan Konsep Investasi Dana Premi BPJS Ketenagakerjaan". Jurnal Balance, Vol. XIV, No. 1, (January, 2017).

www.bpjsketenagakerjaan.go.id, retrieved January 10, 2019. 